\title{
Evaluation of the Performance of Water Supply System in Wolaita Sodo Town, Snnpr, Ethiopia
}

\author{
Wondimu Elias \\ MSc, Department of Hydraulic \& Water Resources Eng'g, Wolaita Sodo University, 138
}

\section{Abstract}

Wolaita Sodo town suffering the shortage of safe water supply service due to increasing population. The aim of study was evaluating the performance of water supply system to develop strategies to improve the situation for the future. It was carried out using six performance indicators suggested by International Water Association (IWA) this was analyzed by SIGMA lite and user perception data that analyzed by SPSS. As study indicates, average consumption for about $73 \%$ of households was less than 20 liter/capita/day. Most of the households (i.e. 53\%) were dependent on public tap, vendors and unprotected spring as a primary water source. About $22 \%$ of households depend on neighboring water vendors and pay high price (i.e. average of $70.6 \mathrm{ETB} / \mathrm{month}$ ) for poor drinking water source. Among the six IWA indicators of water supply service; operational indicators and quality of service indicators fully showed a good performance. However, from water resource indicators (consumer satisfaction \& production/person/day); from personnel indicators (employees/connection), all physical indicators and from financial indicators (water tariff) need some improvement. Generally as the results of the study shows, there was a shortage of water supply service in the town due to the problem of existing water supply system.

Keywords: Access, demand forecast, performance indicators, Performance evaluation, water supply services, DOI: $10.7176 / \mathrm{CER} / 13-1-02$

Publication date: January $31^{\text {st }} 2021$

\section{Introduction}

Water is a very basic necessity of life. The planet earth has enormous quantity of water, but usable water is very limited (1). The demand of water is continuously increasing due to increase in population, industrialization, urbanization and improved standard of living (2). About $75 \%$ of earth is covered by water. But from this high amount only $3 \%$ of it is available as fresh water, which is found in lakes, rivers, springs, ice and ground water etc. Even this little amount of fresh water is not found evenly distributes in all parts of the earth (3). To evaluate and monitor the rate of success, or failure, in meeting this objective, water supply utilities employ a set of Performance Indicators (PIs), quantitative data, which reflect on the performance of various components of the water supply system (2). The ultimate goal of a PI is not merely statistical evaluation but rather to provide information that aids in decision-making. Hence, the usefulness of PIs does not only pertain to water supply undertakings but also to regional/ national planning bodies, regulatory agencies, funding, etc. The first step towards a sustainable water supply system is to evaluate the performance of a given WSS, which further provides the basis for detailed investigations (detailed condition assessment. The performance of a WSS can be assessed by selecting suitable performance indicators (PIs) (4). Wolaita Sodo is one of the developing towns in Ethiopia in which there is a growing demand for water and sanitation services in the town due to growing populations, rising standards of living and per capita incomes. However, the demand for water in the town is growing much faster than the supply. As the household survey carried out by the socio economic group of the consultant, it was reported that about $59.9 \%$ of the households get safe water whereas the remaining $40.1 \%$ do not have safe water supply access (5). This shows the shortage of the water in the town. One of the causes for this problem is that the existing water supply system in the town is not performing as intended by its design. The current water production is $953,650 \mathrm{~m}^{3} /$ year or $2612.74 \mathrm{~m}^{3} /$ day. An average annual water loss of the town is $143,047 \mathrm{~m}^{3} /$ year. To this effect these households use unprotected sources such as un-protected spring, hand dug well and river (6). Therefore, this research is conducted in this town to assess the performance of the existing water supply system by using user perceptions and IWA performance indicator system of water resource, personnel, physical, operational, quality of service and financial and then the strategy is developed to improve the current situation of the water supply system in the town.

\section{Objectives}

The main purpose of this study is to develop strategies to improve water supply services in the town by evaluating the performance of the existing water supply system. To achieve this objective, evaluation of the performance of water supply system at a local level by using end user perceptions and at town level by using IWA system performance indicators such as water resources (WR), personnel (Pe), physical ( $\mathrm{Ph})$, operational (Op), quality service (QS) \& financial (Fi) was carried out, then comparing of its performance at different areas of the town and also with external ADB (Asian Development Bank) water supply system evaluation criteria was carried out and finally measures and strategies were suggested to improve the water supply service situation in the town. 


\section{Methodology}

\section{Study area background}

Wolaita Sodo is a town and separate woreda in south-central Ethiopia. The administrative center of the Wolaita Zone of the Southern Nations, Nationalities, and Peoples Region, it has a latitude and longitude of $6^{\circ} 54^{\prime} \mathrm{N} 37^{\circ} 45^{\prime} \mathrm{E}$ with an elevation between 1,600 and 2,100 meters (5,200 and 6,900 feet) above sea level. The total area of the town is 8,300 hectar (7).

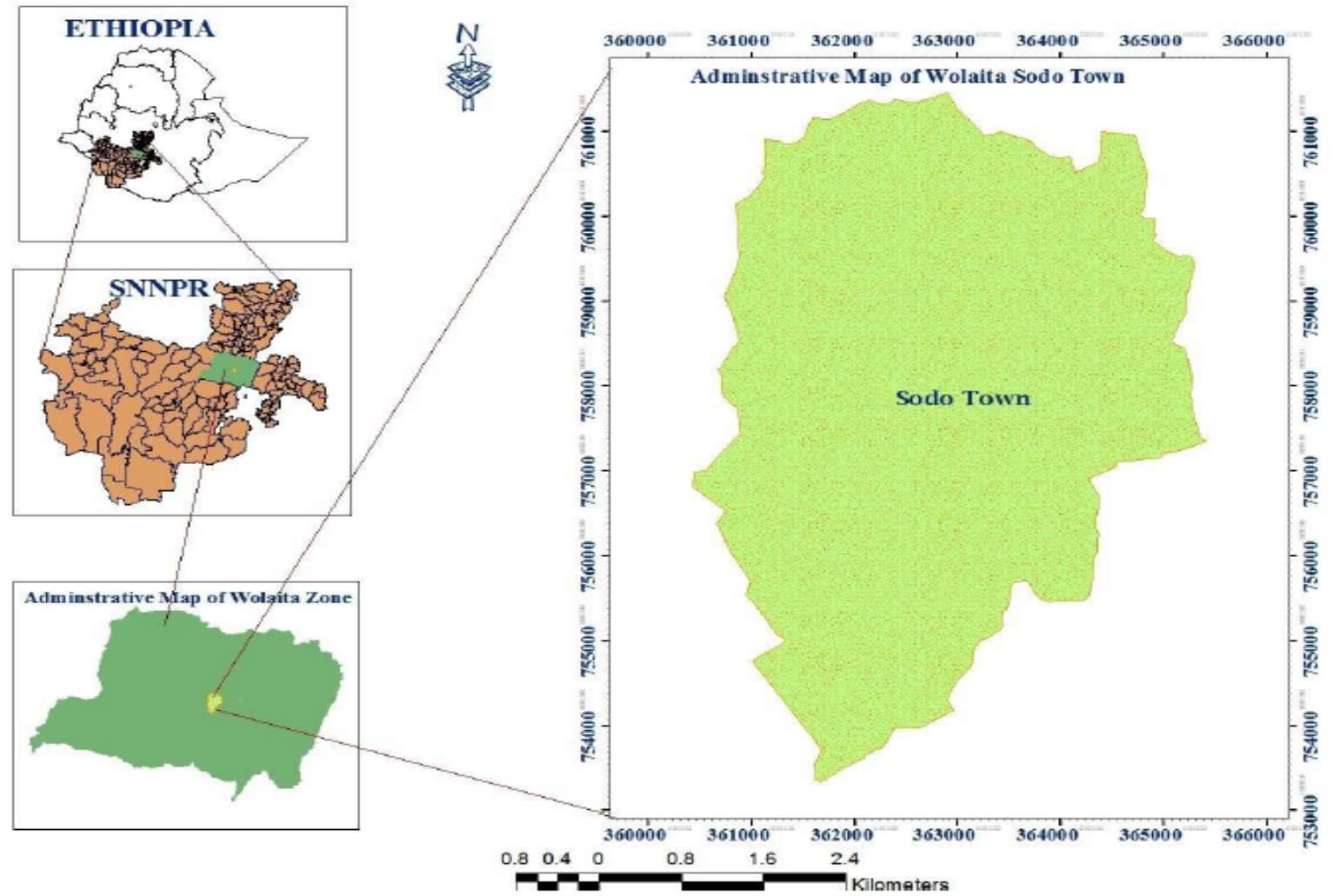

Figure 1: Location map of Sodo town

\section{Indicators selected for data collection}

To analyze the performance of the water supply system at local (end users) level, questionnaire regarding to the following indicators prepared. These are; water quantity supplied to users, water quality supplied to users, reliability for continuity, convenience of the water points, proportion of the household using different types of facilities, and volume of water used and for what purpose (4).

To analyze the performance of the water supply system at town level, six IWA systems of performance indicators selected. These are; Water resources (WR), Personnel (Pe), Physical (Ph), Operational (Op), Quality of service (QS) and Economic \& financial (Fi) (4). 


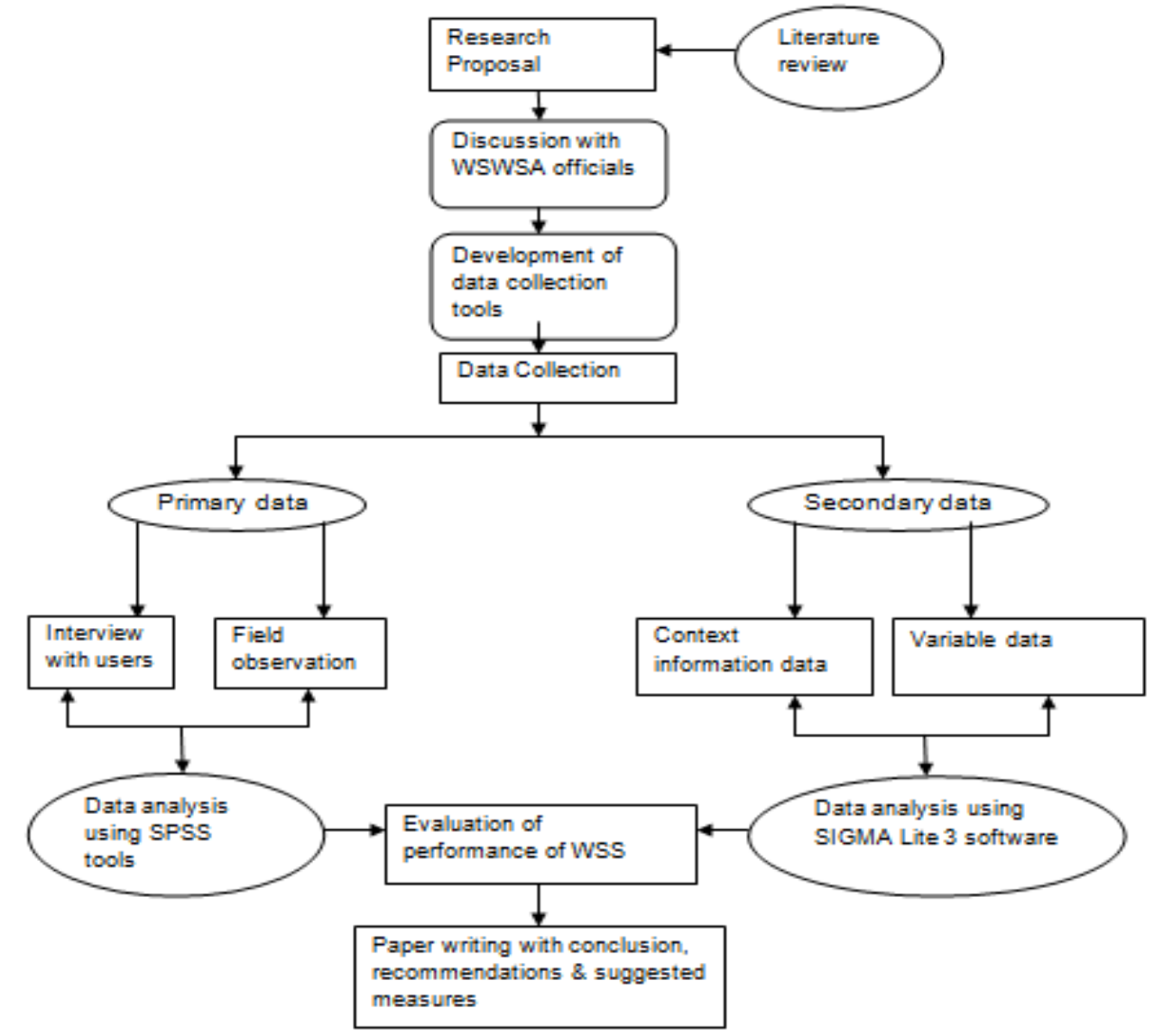

Figure 2: Research methodology process diagram

Data and data collection tools

Both primary and secondary data were used in this study. One of the data collection tool used was pre-prepared questionnaire and the other is data collection checklists (variable and context information checklists). Field visit, discussions with the town water experts and other stakeholders and also referring different documents and websites that deals about the town water supply system were carried out.

\section{Field data collection, Sampling and Sample design}

The field data collection consisting of interviews of the selected sample households from 3 sub cities (i.e. Merkato, Mehal and Arada) that contain 13 kebeles and 5 sub kebeles of the town and data gathering from different stakeholders related to the water supply system in the study area and checklists guided issues which have been investigated during the data collection as discussed in the previous sections. To collect the questionnaire based data from the end users of the town water supply service, a systematic and purposive sampling technique were applied. Generally, to collect the user perception data from the town, the town was divided in to sub cities and then the sub cities were divided into kebeles \& sub kebeles and then in each kebeles \& sub kebeles, the criteria like socio economic growth (i.e. high, medium \& low ), the areas with different conditions of the water supply service (i.e. with access and without access) to existing water supply service and connection type (House connection, yard own connection, yard shared connection, public tap and others) were applied to select the sample households. To make the study meaningful and more effective, 300 sample households were selected out of the total 19,877 households.

\section{Data analysis}

The performance of the existing water supply system situation of the towns at local level was analyzed by using the statistical software called SPSS (Statistical Package for the Social Sciences) for user perception data's and the performance of the existing water supply system situation at the towns level was analyzed by SIGMA lite 3 for international water association (IWA) system of performance indicators (PIs). Then depending on the results, the existing water supply system performance status of the two study towns' compared and then further suggestions and recommendations that will help to improve the water supply system situation in the town was done. 


\section{Results and discussion}

Results of performance evaluation at local level

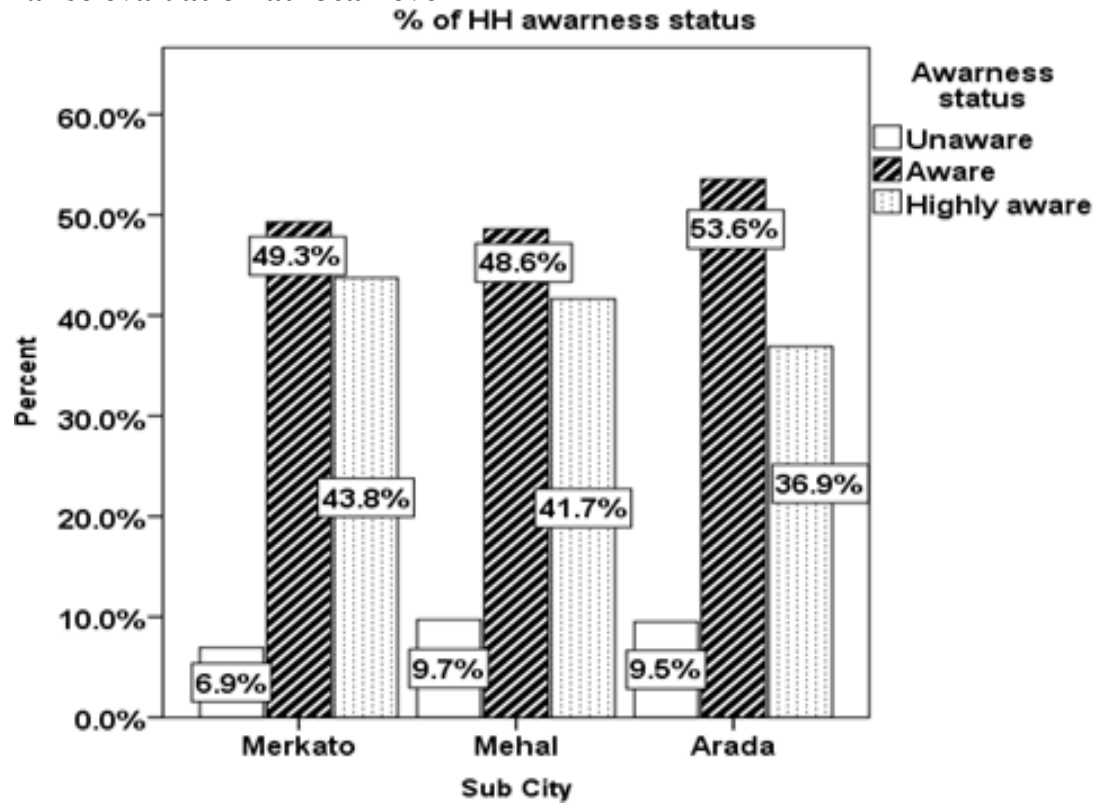

Figure 3: Comparison of health and hygiene awareness in sub cities

As fig 3 shows, the awareness status in the three sub cities of the study area is slightly different and this is because of the different factors in the different areas.

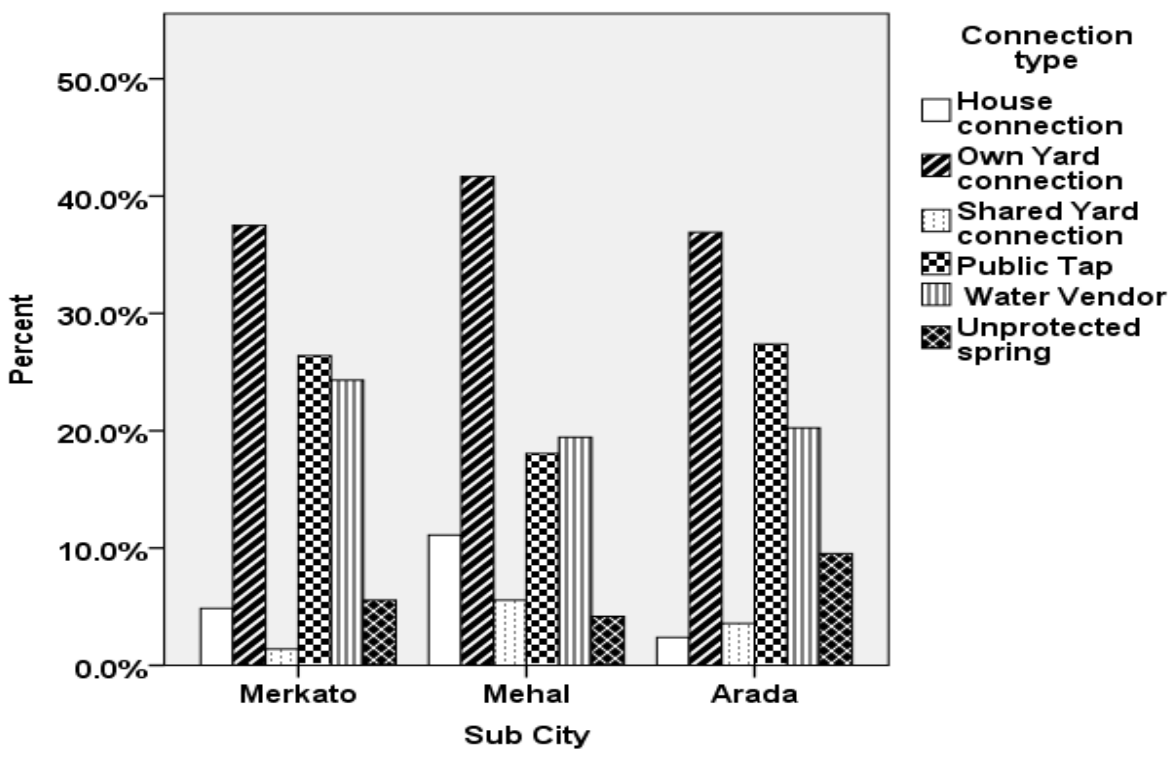

Figure 5: Comparison of primary water sources in three sub cities

As fig 4, most of the households in all three sub cities of the town get their primary water from own yard connection and then from public taps and vendors. But due to the difference in their living standards and economic status of the households, the percentages of the households that uses these water sources is slightly different in different sub cities. For instance, the households that get their primary water from the public tap are $26.4 \%$ in Merkato, $18.1 \%$ in Mehal and 27.4\% in Arada. 


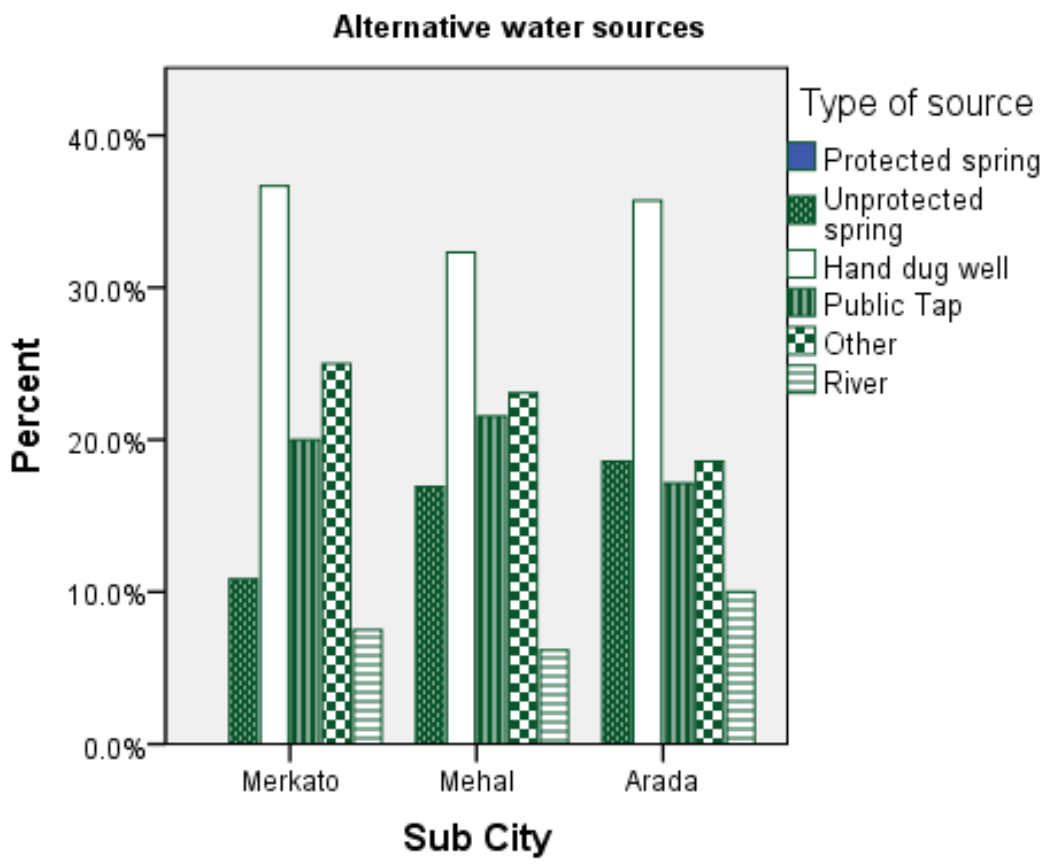

Figure 5: Comparison of alternative water sources in three sub cities

As fig 5 shows, in Merkato and Arada sub cities, the percentage of households that use the alternative water source is similar i.e. $83.3 \%$ and remaining $16.7 \%$ of the households do not have alternative water sources. The percentage of households that have alternative water source in Mehal sub city was greater than that of Merkatos and Aradas. Generally, as the results from primary and alternative water sources shows, still know there is a shortage of the water in the town i.e. the existing water supply system is not accessible for the whole households of the town. Due to this as the above results from the primary and alternative water sources indicates, from the total households of the town, about $20.4 \%$ (6.3\% primary and $14.1 \%$ alternative) of the town households use unprotected spring near their areas for the drinking purposes. Since the water from this source is unprotected and untreated, it may cause both water born and water related disease.

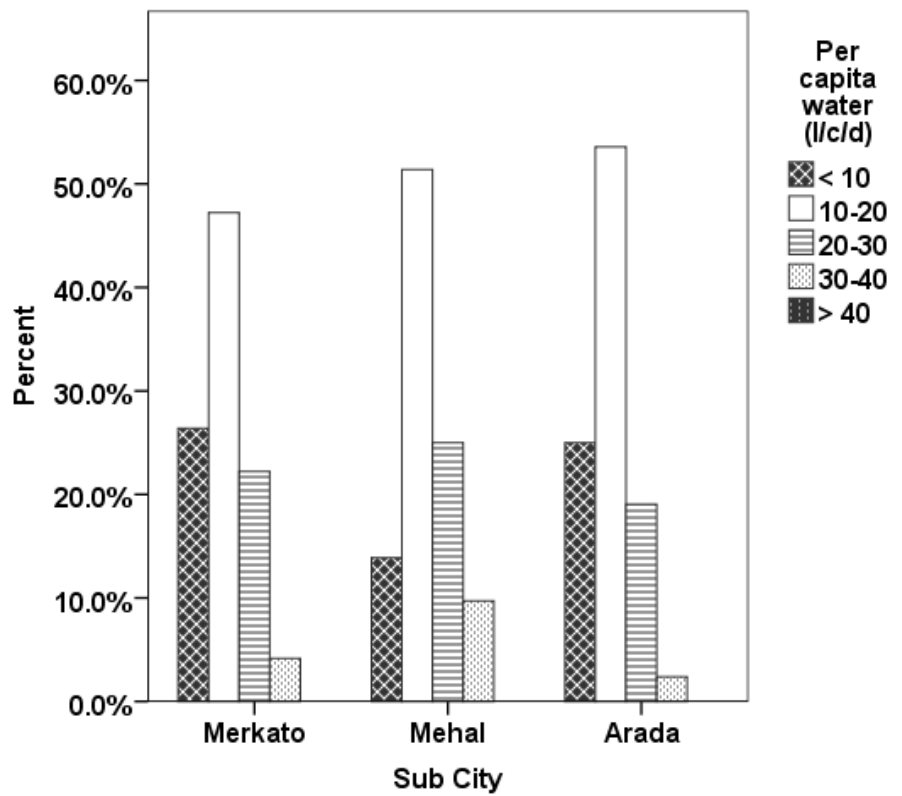

Figure 6: Comparison of per capita water use $(1 / \mathrm{c} / \mathrm{d})$ in three sub cities

As shown in fig 6, most of the households per capita water consumption was in range of 10-20 lcd. In Merkato 47.2\%, In Mehal 51.4\% and in Arada 53.6\% of households' water use was in the range of 10-20 lcd. Percentages of $\mathrm{HH}$ in the range of 20-30 lcd water use were, $22.2 \%$ in Merkato, 25\% in Mehal and 19\% in Arada sub city. Generally in all sub cities, the per capita water use was different as the above result in fig and table shows. The reason for this difference is that the households are different in standard of living, water source they use, number of people in households, etc. 
Table 1: Summary of projected current and future water demands

\begin{tabular}{|c|c|c|c|c|c|c|c|}
\hline \multirow[t]{2}{*}{ Descriptions } & \multirow[t]{2}{*}{ Unit } & \multicolumn{6}{|c|}{ Year } \\
\hline & & 2016 & 2020 & 2025 & 2030 & 2035 & 2040 \\
\hline Population & no & 89430 & 105368 & 128055 & 154078 & 183545 & 216472 \\
\hline Domestic water demand & $\mathrm{m}^{3} / \mathrm{d}$ & 2467.0 & 2530.1 & 3610.1 & 5052.5 & 6946.2 & 9376.3 \\
\hline Non domestic demand & $\mathrm{m}^{3} / \mathrm{d}$ & 1171.8 & 1265.1 & 1917.9 & 2715.7 & 3803.1 & 5274.2 \\
\hline \multirow[t]{2}{*}{ Average Day Demand } & $\mathrm{m}^{3} / \mathrm{d}$ & 3638.8 & 3795.2 & 5527.9 & 7768.1 & 10749.3 & 14650.4 \\
\hline & $1 / \mathrm{s}$ & 42.1 & 43.9 & 64.0 & 89.9 & 124.4 & 169.6 \\
\hline \multirow[b]{2}{*}{ Maximum Day Demand } & $\mathrm{m}^{3} / \mathrm{d}$ & 4184.6 & 4364.5 & 6080.7 & 8545.0 & 11824.2 & 16115.5 \\
\hline & $1 / \mathrm{s}$ & 48.4 & 50.5 & 70.4 & 98.9 & 136.9 & 186.5 \\
\hline \multirow[t]{2}{*}{ Peak Hour Demand } & $\mathrm{m}^{3} / \mathrm{d}$ & 6549.8 & 6072.3 & 8844.7 & 12429.0 & 17198.9 & 23440.7 \\
\hline & $1 / \mathrm{s}$ & 75.8 & 70.3 & 102.4 & 143.9 & 199.1 & 271.3 \\
\hline Total daily supply into network & $\mathrm{m}^{3} / \mathrm{d}$ & 3638.8 & 3795.2 & 5527.9 & 7768.1 & 10749.3 & 14650.4 \\
\hline Total annual supply into network & $\mathrm{m}^{3} / \mathrm{y}$ & 1328160 & 1385255 & 2017701 & 2835373 & 3923496 & 5347403.4 \\
\hline $\begin{array}{l}\text { Required annual production } \\
\text { capacity }\end{array}$ & $\mathrm{m}^{3} / \mathrm{y}$ & 1328160 & 1385255 & 2017701 & 2835373 & 3923496 & 5347403.4 \\
\hline
\end{tabular}

\section{Water supply gaps and service level benchmark in the town}

\section{Indicators \\ Benchmark \\ Current status}

Water supply coverage

Production $1 / \mathrm{c} / \mathrm{d}$

100

$82.79 \%$

$50 \mathrm{l} / \mathrm{c} / \mathrm{d} \quad 301 / \mathrm{c} / \mathrm{d}$

$17.21 \%$

Demand \& Supply $\quad 3638.8 \mathrm{~m}^{3} / \mathrm{d} \quad 2612.7 \mathrm{~m}^{3} / \mathrm{d} \quad-1026.1 \mathrm{~m}^{3} / \mathrm{d}$

Note: Production/person/day $=3638.8 / 74039 \approx 0.05 \mathrm{~m}^{3} /$ person $/$ day $=50$ liters $/$ person $/$ day

The present daily average input in to the water supply system is $2612.7 \mathrm{~m}^{3} / \mathrm{d}\left(953,650 \mathrm{~m}^{3} / \mathrm{year}\right)$. But in the town there is a shortage of the water as the above result shows. But to improve the existing water service problem in the town, the system input volume have to be improved. These existing and expected future sources will make a total supply of about $3638.8 \mathrm{~m}^{3} /$ day equal to about $1328160 \mathrm{~m}^{3} /$ year. As the data from the town water supply organization indicates, the current available supply of water to the town is $953,650 \mathrm{~m}^{3} /$ year) and is found lower than the required annual production capacity at present i.e. $1328160 \mathrm{~m}^{3} /$ year.

Results of performance evaluation at town level

Table2: SIGMA Lite software results of selected performance indicator

\begin{tabular}{|l|l|l|l|l|}
\hline Code & Name & Units & Value & Confidence grades \\
\hline Fi46 & Non-revenue water by volume & $(\%)$ & 15.07 & A3 \\
\hline Fi47 & Non-revenue water by cost & $(\%)$ & 43.77 & B3 \\
\hline Op23 & Water losses per connection & $(\mathrm{m} 3 /$ connection/year $)$ & 20.12 & B3 \\
\hline Op42 & Microbiological tests carried out & $(\%)$ & 62.5 & B3 \\
\hline Op43 & Physical-chemical tests carried out & $(\%)$ & 62.5 & B3 \\
\hline Pe1 & Employees per connection & $($ No./1000connections $)$ & 4.92 & A2 \\
\hline Pe13 & Water quality monitoring personnel & $($ No./(10000tests/year $))$ & 10000 & B3 \\
\hline Pe14 & Meter management personnel & $($ No./1000meters $)$ & 0.14 & A2 \\
\hline Pe9 & Operations \& maintenance personnel & $(\%)$ & 71.43 & A3 \\
\hline Ph12 & Metered customer & $($ No./customer $)$ & 1 & A2 \\
\hline Ph2 & Raw water storage capacity & $($ days $)$ & 0.88 & B3 \\
\hline Ph3 & Treated water storage capacity & $($ days $)$ & 0.15 & B3 \\
\hline QS20 & Microbiological tests compliance & $(\%)$ & 98.67 & A1 \\
\hline QS21 & Physical-chemical tests compliance & $(\%)$ & 100 & A1 \\
\hline QS3 & Population coverage & $(\%)$ & 82.79 & A2 \\
\hline QS4 & Population coverage with service connections & $(\%)$ & 38.3 & A2 \\
\hline QS5 & Population coverage public taps & $(\%)$ & 44.49 & A2 \\
\hline QS8 & Per capita water consumed in public taps & $(1 /$ person/day) & 28 & B2 \\
\hline QS9 & Population per public tap & $($ persons/tap $)$ & 1101.9 & A2 \\
\hline WR1 & Inefficiency of use of water resources & $(\%)$ & 10.3 & B2 \\
\hline WR2 & Water resources availability & $(\%)$ & 43.51 & B2 \\
\hline
\end{tabular}

Water resources indicators $(\mathrm{WR})$

Production per person per day is one of the measures of overall efficiency of water resource use. The result of this parameter is $0.03 \mathrm{~m} 3 /$ person/day (30 liters/person/day) This figure is small when compared with the ADB water supply system evaluation criteria value i.e. average of $50 \mathrm{l} / \mathrm{c} / \mathrm{d}$. Inefficiency of use of water resources (WR1) was another performance indicator of the water supply system. The result of this indicator was $10.3 \%$. This indicator depends on the variables include real loss and system input volume. As real losses increase, inefficiency of use of water resources increases.

Personnel indicators (Pe)

The result of skilled labor (Operation and maintenance personnel) was $71.43 \%$ as table 2 shows. If compared with 
the last ten years the authority made an increment of the skilled personnel by $11 \%$. This reflects that the Sodo Town Water Supply \& Sewerage Organization has enough efficiency in terms of staff numbers. One the other hand employees/1000 connections was indicator of the personnel performance. As the result in the table 2 shows, the authority has 4.92 employees/ 1000 connections. When compared with Bereket Belayhuns value for selected areas of Addis Ababa i.e. 6.62 employees/1000 connections, the value was still small.

\section{Physical indicators $(\mathbf{P h})$}

As table 2 shows, the storage capacities i.e. the raw water storage capacity $(\mathrm{Ph} 2)$ and treated water storage capacity (Ph3) figures for the town existing water supply system are very low i.e. 0.88 and 0.15 respectively in days. This indicators depend on the variables include system input volume, assessment period, treated and raw water storage volumes in cubic meter. When this value compared to the Bereket Belayhuns value for selected areas of Addis Ababa, i.e. 319.08 days \& 0.4 days, it was very small.

\section{Operational indicators (Op)}

A water loss per connection (Op 23) is one of the major operational performance indicators. Its result in $\mathrm{m}^{3} /$ connection /year was 20.12. It depends on total water losses of the system, number of service connections and assessment period. As the total water losses of the system increase, the value of this indicator also increases. When this value compared to the Bereket Belayhuns value for selected areas of Addis Ababa,i.e $119.92 \mathrm{~m}^{3} / \mathrm{connection}$ /year, it was very small. Microbiological tests carried out (Op42) and physical chemical tests carried out (Op43) were the other operational performance indicators. The results of these indicators were $62.5 \%$. These indicators depend on the variables of required microbiological \& physical chemical tests carried out and microbiological \& physical chemical tests required. When these values compared to the Bereket Belayhuns value for selected areas of Addis Ababa, i.e. $96.96 \%$ and $100 \%$, its value was low but better than other indicators.

\section{Quality of service indicators (QS)}

The quality of the supplied water in the town is also very encouraging as the result of microbiological and physical chemical quality of supplied water shows in the table above i.e. $98.67 \%$ and $100 \%$ respectively. When it compared to ADB criteria of the quality of water supplied to consumers i.e. $\geq 95 \%$, the value is in the higher side. When these values compared to the Bereket Belayhuns value for selected areas of Addis Ababa, i.e. 98.8 \% and 99.57\%, it was better in sodo town. Coverage (QS3) is another indicator of quality of service and its value was $82.79 \%$. As it compared to the Bereket Belayhuns value for selected areas of Addis Ababa i.e. $85 \%$, it was encouraging that could be managed in few years.

\section{Financial indicators (Fi)}

Non-revenue water by cost (Fi46) was one of economic and financial performance indicator of the public water supply system. It depends on the variables include unbilled authorized consumption, apparent losses, real losses, running costs and average water charges for the direct consumption. The result of this indicator was $43.77 \%$ as indicated in table 2 above. When this value compared to Bereket Belayhuns value for selected areas of Addis Ababa, i.e. $26.99 \%$ it was better in Sodo town.

\section{Improvement Measures}

From the results of the performance indicators discussed in the preceding sections, the suggested improvement measures to improve the existing situation of safe water service in the town include the following but not limited to:

i. Greater service level and coverage

ii. Availability of water for 24 hours

iii. Water demand management by public awareness

iv. Promotion of private tap connections and gradual elimination of public taps (extensive use of public taps represents low level of service and reduce water accountability potential)

v. Additional reduction of water losses

vi. Encouraging large water consumers other than drinking to dig wells of their own

vii. Efficient water meter reading and $100 \%$ metering so that the volume of water consumed and water losses can accurately be known

viii. Appropriate reports and records of the water supply situation

ix. Creation of water conservation awareness

$\mathrm{x}$. Promote water saving devices

xi. Upgrading and maintenance of the existing system

\section{Strategies for improving water services in the town Short term strategies}

Operation and maintenance: upgrading and rehabilitation of the existing raw and treated water reservoirs as well as distribution system

Advocacy for the water supply sector: all stakeholders in the sector including Sodo Town Water Supply \& 
Sewerage Organization, Sub cities water and sewerage offices, users, Sodo town administration authority, and NGOs should take part in advocating the sector for more investments.

Public private partnership: In addition to the public sector and communities, the private sector has to play a vital role in improving the access of safe water supply service in the town. This is because the lack of efficiency in the public management of human, financial and water resources, resulting in poor service to the consumer can be improved and the private sector can also bring in funding for capital development.

Capacity building: the Sodo Town Water Supply \& Sewerage Organization should follow intensive capacity building for its staff (in technical, management and social aspects) to accomplish the mission.

Long term strategies

Development of new water sources: the already studied water sources of the town that were 11 boreholes with estimated yield of $66 \mathrm{l} / \mathrm{s}$ at a some well field should be developed to improve the shortage of water in the town. New raw and treated water reservoirs should be constructed for this source including transmission lines.

Reduction of Unaccounted-for water: the UFW in Sodo town water supply should be reduced by carrying out the following:

Phasing out of public taps, tracing of invisible leaks (preventive leakage management), and replacing of old pipes in all areas

Expansion of services for the poor: preparing subsidy for connection fees of the poor that will be paid back through monthly installment basis.

Monitoring of performance: the Town Water Supply \& Sewerage Organization should monitor the performance of its own water supply system periodically

\section{Some constraints in achieving fully improved water supply service in the town}

Natural factors: sustainable availability of water resources at all times is the main factor in the water supply sector (drought may reduce the water resource availability).

Technical factors: there is lack of availability of technology that suits sustainability through linking design to business planning.

Weak community management: presently community management is rather weak in empowering and involving the community in all levels of the programme planning.

Limited external financing: the limited external funds for achieving the fully improved safe water supply service in the town.

\section{Limitations of study}

Out of the total 19,877 households in the town, only 300 sample households were taken for the study. Therefore, this study gives a general overview of the situation. The water quality test of the different water collection sources at household level was not done. This study focuses more on the quantity of water available, service level and costs.

\section{Conclusions}

Generally this study was carried to evaluate the performance status of the town existing water supply system and to compare it in different areas in town and with some external water supply service to develop the strategies to improve the existing situation in the town. An increase in population of the town was due to people migrating from rural areas and natural increase has resulted for high demand in drinking water and has placed a strain on existing service provision. The per capita water uses of about $73 \%$ of the households are below basic access (i.e. below 20 lcd) according to WHO (2003) standards. While for the rest of the households it is in the range of basic access. Hence it can be concluded that most of the town households are not accessed by improved water supply. Most of the households i.e. about $53 \%$ of households are dependent on public tap, vendors and unprotected spring as a primary water source and walk on average of more than 15 minutes in collecting water. The households are forced to travel to neighboring areas spending on average of 1.5 hour whenever water supply interruptions occur in the area. The water supply system in town is not reliable as there are interruptions of service in weeks. In such situation, households get water from the alternative sources. It was found that households who depend on vendors $(22 \%)$ pay an average of ETB 70.6/month for water they used which was about 8.8 times the unit cost set by Sodo Town Water Supply Organization water tariffs for public taps and 10.4 times the unit cost set by STWSO water tariff for service pipes. This is an indication of low services and the households are consuming little water but spending high costs than the tariff set by the town water supply organization. About $77.6 \%$ of unconnected respondents are prepared to have own yard connection, $12.9 \%$ shared yard connection and the rest $9.4 \%$ public taps showing that the water vendors and unprotected springs are not the preferred options among the unconnected households. This indicates that the households are currently using these sources because they have no choice. The quantity of water available from the existing water sources of the town $953,650 \mathrm{~m}^{3} / \mathrm{y}$ is found to be lower than the actual demand of the town $1328160 \mathrm{~m}^{3} / \mathrm{y}$. The performance evaluation of the town water supply system with regard to certain 
indicators shows improvements in terms of water recourse indicators (production/person/day), in terms of personnel indicators (employees/1000connections), in terms of physical indicators (storage capacity), in terms of financial indicators (water tariff) and the ADB system was in an encouraging situation in terms of operational indicators, quality of service indicators, personnel indicators $(\mathrm{O} \& \mathrm{M}$ personnel), water resource indicators (inefficiency of use of water resources, resource availability). Generally the study indicates that the sodo town existing water supply system should have to be improved to solve the existing water service problem in the town.

\section{Acknowledgment}

Firstly I would like to thank Wolaita Sodo University for encouraging and sponsoring the research. Secondly, thanks to the sample respondents of the study area for their open expressions and thoughts they have during the collection of all necessary information's and lastly I am happy to thank Sodo town water supply \& sewerage office and administration offices for their assistance in providing any necessary data and information's for the research.

\section{Abbreviations}

IWA. International Water Association

SPSS Statistical Packages for Social Sciences

ETB Ethiopian Birr

PIs... Performance Indicators

WSS Water Supply Service

\section{References}

1. Public Water Supply Demand and Resource Managment. Mieraf.S and Adnew.A. Addis Ababa : s.n., 1999. 25th WEDC Conference.

2. Belindah.N. Assessment of Performance of urban water supply in the city of Bulawawo. Bulawawo : s.n., 2011.

3. Rao.S.P. Intermediate Vocational Course, 1st year: Water Supply Engineering (For the Course of Water Supply and Sanitation Engineering). First Edition. 2005.

4. Helena Alegre, Jaime Melo Baptista, Enrique Cabrera Jr., Francisco Cubillo. Performance Indicators for Water Supply Services. Second Edition. London : IWA Publishing, 2006.

5. Doyen.J, Manou.S.A, Pilgrim.N, Roche.R, Valfrey.B, Fiset.S, Gicheru.N and Chalkim.H. Summary of International Conference on Water Supply and Sanitation for Small Towns and Multistage Schems. Addis Ababa : s.n., 2002.

6. Toubkiss.J. Costing MDG target 10 on Water Supply and Sanitation: comparative analysis, obstacles and recommendations. s.1. : World Water Council, 2006.

7. Sodo, Wolaita. Wikpedia the free encyclopedia. [Online] 2011. https://en.wikipedia.org/wiki/sodo.

8. ADB. Second water utilities data book . [ed.] National Library. Manila : Asian Development Bank, 2005.

9. Boyd.D. Growing Cities and Precious water, a need for better managment and exchange of knowledge Lecture Notes. IHE Delft : s.n., 2005.

10. Brocklehum.C and Evans.B. Serving poor consumer in South Asian Cities, private sector participation in water and sanitation, water and sanitation program. New Delhi : s.n., 2001.

11. Cairn cross.S, Carruthers.I, Curtis.D, Feachem.R, Bradley.D, Baldwin.G. Evaluation for village water supply planning. New York: John Wiley and Sons, 1980.

12. Coelli.T.J, Estache.A, Perelman.S, Trujillo.L. A Primer on Efficiency Measurment for Utilities and Transport Regulators. s.l. : World Bank Publications , 2003.

13. Colligon.B and Vezina.M. Independent Water and Sanitation Providers in African Cities, Full report of a tencountry study. s.l. : IRC, 2000.

14. CSA. The 1994 Population and Housing Cencus of Ethiopia, the result for S.N.N.P.R, Statistical Report. Addis Ababa : Central Statistical Authority, 1995. Vol. Volume I.

15. OESP. Who are the question makers? A participatory Evaluation Handbook. 1997.

16. Sharma.S. Decentralized Water Supply and Sanitation. IHE Delft : s.n., 2005.

17. UN-HABITAT. United-Nations Center for Human Setlments (UN-HABITAT) Water and Cities. Kyoto : s.n., 2003.

18. Enterprize, Sodo Town Water and Sewerage. Water Supply and Sanitation Design Report of Sodo Town. Sodo Town Water and Sewerage Enterprize. Wolaita Sodo : s.n., 2009.

19. WHO. Domestic Water Quality, Service level and Health. Jeneva : s.n., 2008.

20. Woldemeskel, Bereket Belayhun. Evaluation of water supply systems in selected urban poor areas of Addis Ababa. Addis Ababa : s.n., 2006. 